\title{
IMPLEMENTASI PROGRAM PUSAT INFORMASI KONSELING MAHASISWA (PIK-M) BKKBN DI KOTA PALANGKA RAYA
}

\author{
Implementation Of Programs Of Information Student Counseling Center \\ (PIK-M) BKKBN In Palangka Raya City
}

\section{Nicodemus R Toun}

Hayatun Nufus

\author{
Universitas Muhammadiyah Palangkaraya, \\ Palangka Raya, Central Kalimantan, \\ Indonesia \\ email: \\ nicodemus.r,toun@umpalangkaraya.ac..id
}

\begin{abstract}
Abstrak
Penelitian ini bertujuan untuk mengetahui dan mendeskripsikan Implementasi Program Pusat Informasi Konseling Mahasiswa BKKBN di Kota Palangka Raya. Jenis penelitian yang digunakan adalah metode kualitatif, dengan mengambil sampel 4 (empat) PIK-M dari 8 (delapan) PIK-M di kota Palangka Raya. Yaitu, (I) PIK-M Barendeng (UNPAR), (2) PIK-M Fasko (UMP), (3) PIK-M Barigas (IAIN), (4) PIK M Bakti Husada (Poltekkes). Teknik pengumpulan data adalah dokumentasi, observasi, dan wawancara. Informan terdiri dari Kepala KS / PK, Kepala Subbagian BKR, Wali Amanat, Manajer, dan anggota masing-masing PHC-M. Landasan teori dalam penelitian ini adalah implementasi dan program, di mana implementasi adalah tindakan untuk mencapai tujuan yang diuraikan dalam keputusan kebijakan. Program adalah sebagai unit atau unit kegiatan yang merupakan realisasi atau implementasi kebijakan yang terjadi dalam proses yang berkelanjutan dan terjadi dalam suatu organisasi yang melibatkan sekelompok orang. Menurut G. Shabbir Cheema dan Dennis a. Rondinelli memiliki empat faktor yang mempengaruhi implementasi kebijakan atau program, yaitu: (a) kondisi lingkungan, (b) hubungan antar organisasi, (c) sumber daya organisasi untuk implementasi program, (d) karakteristik dan kemampuan agen pelaksana.
\end{abstract}

Kata Kunci:

Implementasi

Konsenling

Program

PIK-M

\section{Keywords:}

Implementation

counseling

Program

PIK-M

\section{Accepted}

Januari 2015

\section{Published}

April 2015

\begin{abstract}
This study aims to find out and describe the Implementation of the BKKBN Student Counseling Information Center (PIK-M) Program in the city of Palangka Raya. The type of research used is a qualitative method, by taking a sample of 4 (four) PIK-M from 8 (eight) PIK-M in the city of Palangka Raya. Namely, (I) PIK-M Barendeng (UNPAR), (2) PIK-M Fasko (UMP), (3) PIK-M Barigas (IAIN), (4) PIK M Bakti Husada (Poltekkes). Data collection techniques are documentation, observation, and interviews. The informants consisted of Head of KS / PK, Head of Sub-Division of BKR, Trustees, Managers, and members of each PHC-M.The cornerstone of theory in this research is implementation and program, where implementation is actions to achieve the objectives outlined in policy decisions. The program is as a unit or unit of activity which is the realization or implementation of policy takes place in a continuous process and occurs in an organization involving a group of people. According to G. Shabbir Cheema and Dennis a. Rondinelli has four factors that influence the implementation of policies or programs, namely: (a) environmental conditions, (b) relations between organizations, (c) organizational resources for program implementation, (d) characteristics and capabilities of implementing agents.
\end{abstract}

\section{PENDAHULUAN}

Remaja merupakan sebuah fase dimana seseorang akan mengalami peralihan dan perubahan tahap baik dari segi emosi, tubuh, minat, perilaku juga masalah lainnya. Seorang remaja akan sering mengalami masalah dengan psikososial yakni masalah psikis (kejiwaan) yang dapat muncul sebagai akibat adanya perubahan. Masa remaja merupakan masa peralihan dari anak anak ke masa dewasa.

Dalam penulisan latar belakang ini penulis memfokuskan pada PIK Mahasiswanya. Jadi Pusat Informasi Konseling Mahasiswa (PIK-M) adalah suatu 
wadah yang dikembangkan dalam program Genre yang dikelola dari dan untuk mahasiswa guna memberikan pelayanan informasi dan konseling tentang pendewasaan usia perkawinan, delapan fungsi keluarga, TRIAD KRR (seksualitas, HIV I AIDS dan NAFZA), keterampilan hidup, gender dan keterampilan advokasi dan KIE.

Keberadaan dan peranan PIK-M sangat penting artinya dalam membantu mahasiswa untuk memperoleh informasi dan penyiapan konselin yang cukup dan benar tentang pentingnya penyiapan kehidupan berkeluarga bagi remaja. Oleh karena itu perlu dilakukan peningkatan pengembangan dan pengelolaan PIK-M dalam rangka meningkatkan akses dan kualitas pengelolaan dan pelayanan tersebut \& Di kota Palangka Raya sendiri telah terbentuk ada delapan (8) PIK- M (Pusat Informasi Konseling Mahasiswa) yang tersebar diberbagai Universitas Negeri maupun swasta. Dalam perkembangannya masing masing memiliki permasalahan dan tantangan yang berbeda, ada yang berkembang dan ada yang hanya jalan ditempat, dan apakah itu disebabkan karena mahasiswa yang kurang tertarik untuk bergabung (berpartisipasi). Sedangkan pada kenyataan dari hasil observasi yang peneliti lakukan masih banyaknya perilaku menyimpang dan beresiko yang dilakukan para remaja atauplm para mahasiswa. Apalagi di era globalisasi ini yang mana kemajuan teknologi informasi yang sangat maju diterima oleh remaja dengan tidak memiliki mana yang baik dan tidaknya maka akan berdampak terhadap tingkah laku dan pola pikir remaja atau mahasiswa itu sendiri. Contohnya seks bebas, mabuk mabukan dan konsumsi narkoba. Hal ini sesuai dengan hasil penelitian yang dilakukan oleh PKBI (Persatuan Keluarga Berencana Indonesia) Kalimantan Tengah dan BKKBN (Badan Kependudukan keluarga Berencana Nasional) Kalimantan Tengah tahun 2012 pada salah satu Universitas yang ada di Kota Palangka Raya menyatakan tercatat sekitar $30,71 \%$ dari 300 sampel remaja Palangka Raya pernah berhubungan seks dan ini sangat mengkhawatirkan karena remaja disini kebanyakan mahasiswa.

Kasus HIV / AIDS di kota Palangka Raya juga mengalami peningkatan yang tajam di tahun 2013 dimana jumlah penderita HIV sebesar 228 kasus dan AIDS 106 kasus yang rata rata didominasi oleh remaja. Dan juga bisa di lihat di pemben'taan dan media massa mengenai maraknya perilaku menyimpang yang dilakukan oleh para remaja.. Untuk itulah keberadaan PIK-M ini sangatlah penting dalam membantu dan memberikan pengetahuan tentang bagaimana menjalankan kehidupan yang sehat jauh dari pergaulan bebas, narkoba dan penyakit seksual lainnya.

Menurut Solichin Abdul Wahab Implementasi adalah tindakan tindakan yang dilakukan oleh individu atau pejabat pejabat, kelompokkelompok pemen'ntah atau swasta yang diarahkan pada tercapainya tujuan- tujuan yang telah digariskan dalam keputusan kebijakan. Implementasi merupakan tindakan tindakan untuk mencapai tujuan yang vtelah digariskan dalam keputusan kebijakan. Tindakan tersebut dilakukan baik oleh individu, pejabat pemerintah ataupun swasta. Menurut Dunn (2003:132) Implementasi adalah pelaksanaan pengendalian aksiaksi kebijakan didalam kurun waktu tertentu .

Menurut Wibawa (1992: 14) implementasi kebijakan merupakan pengejawantahan keputusan mengenai kebijakan yang mendasar, biasanya dalam suatu undang-undang dan namun juga dapat berbentuk instruksi instruksi eksekutif yang penting atau keputusan perundangan . Idealnya keputusankeputusan tersebut menjelaskan masalah- masalah yang hendak ditangani, menentukan tujuan yang hendak dicapai dan dalam berbagai cara menggambarkan struktur proses implementasi tersebut. Secara sederhana tujuan implementasi kebijakan adalah untuk menetapkan arah agar tujuan kebijakan publik dapat direalisasikan sebagai hasil dari kegiatan pemerintah Keseluruhan proses penetapan kebijakan baru bisa 
dimulai apabila tujuan dan Berkaitan dengan faktor yang mempengaruhi implementasi kebijakan suatu program. Menurut pendapat Cheem dan Rondinelli (Suharsono, 2013) mengemukakan bahwa terdapat beberapa faktor yang mempengaruhi implementasi kebijakan/ program program pemerintah yang bersifat desentralistis. Faktor faktor tersebut diantaranya:

I. Kondisi lingkungan Lingkungan sangat mempengaruhi implementasi kebijakan, yang dimaksud lingkungan ini mencakup lingkungan sosio kultural serta keterlibatan penerima program

2. Hubungan antar organisasi.

Dalam banyak program, implementasi sebuah program perlu dukungan dan koordinasi dengan instansi lain. Untuk itu diperlukan koordinasi dan kerjasama antar instansi bagitkeberhasilan suatu program

3. Sumber daya organisasi Imtuk implementasi program. Implementasi kebijakan perlu didukung sumberdaya baik sumber daya manusia (human resources) maupun sumber daya non-manusia (non human resources).

4. Karakteristik dan kemampuan agen pelaksana Yang dimaksud karakteristik dan kemampuan agen pelaksana adalah mencakup struktur birokrasi, norma norma, dan pola- pola hubungan yang terjadi dalam birokrasi, yang semuanya itu akan mempengaruhi implementasi program.

\section{METODOLOGI}

Pendekatan Penelitian ini menggunakan deskriftif kualitatif dalam menggambarkan secara sistematis mengenai fakta-fakta serta hubungan antara fenomena yang diselidiki, yang berhubungan dengan masalah atau gejala yang terjadi. Lokasi penelitian ini ada di KPU Kota Palangka Raya.

\section{HASIL DAN PEMBAHASAN}

Berdasarkan hasil penelitian dilapangan tentang implementasi program Pusat Informasi Konseling Mahasiswa (PIK-M) dari data yang diperoleh dapat dijelaskan bahwa implemntasi program Pusat Informasi Konseling Mahasiswa (PIK-M) di Kota Palangka Raya dilaksanakan dalam rangka peningkatan kaulitas remaja dengan memberikan akses informasi, pendidikan, konseling dan pelayanan tentang kehidupan berkeluarga. Artinya keberadaan dan peranan PIK-M sangat penting dalam membantu mahasiswa untuk memperoleh informasi dan penyiapan kehidupan berkeluarga bagi remaja.

BKKBN sebagai fasilatator, BPP KB kota dan pihak Universitas sebagai perpanjangan tangan dalma hal ini sebagai pembina, pemantau dan pengelola dari program ini. Sebenarnya sudah melaksanakan tugasnya namun belum termaksimalkan yang disebabkan oleh keterbatasan dana yang dimiliki juga kurangnya koordinasi dari berbagai pihak yang terlibat dalam program PIK-M.

\section{KESIMPULAN}

Implementasi program pusat informasi mahasiswa (PIK-M) di Kota Palangka Raya sudah dilaksnakaan tetapi belum dikatakan berhasil, artinya masih belum berjalanan dan belum sesuai dengan apa yang menjadi keinginan program. Berbagai faktor dari implementasi program seperti bagaimana kondisi lingkungan, hubungan antar organisasi, sumber daya organisasi dan karakteristik dan kemampuan agen pelaksana yang sampai saat ini masih kurang dapat termaksimalakan. BKKBN sebagai pelaksana program tidak hanya sebatas menyampaikan kepada pihak universitas untuk mendirikan organisasi di tiap kampus, tetapi untuk bersikap lebih aktif demgan memberikan pemantauan, monitoring dan evaluasi kembali apa-apa yang menjadi hambatan dalam menjalankan program PIK-M ini. 
Para mahasiswa yang juga dijadikan sebagai pengurus dan anggota PIK-M masing-masing, sebenarnya harus mempunyai rasa tanggung jawab yang penuh dalam mengelola dan melaksanakan kewajiban di organisasi ini, walaupun sejatinya mereka mempunyai kesibukan dan tugas masing-masing. Namun diharapkan adanya bantuan, perhatian dan pembinaan dan evaluasi bagi para pelaksana program serta pihak-pihak yang terkait secara berkesinambungan demi tercapainya program yang diinginkan yaitu menjadikan PIK-M sebagai sumber informasi yang dapat menambahkan pengetahuan dan keterampilan mahasiswa tentang perencanaan kehidupan berkeluarga bagi mahasiswa.

\section{REFERENSI}

Agustino, Leo. 2012. Dasar-Dasar Kebijakan Publik. Bandung : CV. Alfabeta.

Basrowi dan Suwandi. 2008. Memahami Penelitian Kualitatif. Jakarta : Rineka Cipta.

BKKBN. 2009. Undang-undnag RI Nomor 52 Tahun 2009 tentang Perkambangan kependudukan dan Pembanguna Keluarga. Jakarta : BKKBN

BKKBN. 20I4. Pengaruh Pendidikan, Tingkat Pengetahuan Kespol/Seksia. Jakarta

Dunn, William N. 2003. Pengantar Analisis Kebijakan Publik. Yogyakarta : Gadjah Mada Universitas Press.

Emzir, 2012. Metodologi Penelitian Kualitatif, Analisis Data. Rajawali Perss.

Ekowati, Mas Roro. 2009. Perencanaan, Implementasi dan Evaluasi Kebijakan atau Program (Suatu Kajian Teoritas dan Praktis)

Mulyadi, Deddy. 2015. Studi kebijakan Publik dan Pelayanan Publik. Konsep dan Aplikasi Proses Kebijakan dan Pelayanan Publik. Bandung : Alfabeta

Muadz, Masri. 2010. Panduan Pengelolaan Pusat Informasi dan Konseling Mahasiswa (PIKMahasiswa). Jakarta : BKKBN, Direktorat Remaja dan Perlindungan Hak-Hak Reproduksi).

Muadz, Masri. 2009. Panduan Pengelolaan Pusat Informasi dan Konseling Remaja (PIK Remaja). Jakarta : Direktorat Remaja dan perlindungan Hak-hak Reproduksi.

Sarwono, Sarlito W. 2012. Psikologi Remaja. Jakarta : Grafindo Persada.
Subarsono. 2013. Analisis Kebijakan Publik, Teori dan Aplikasi. Yogyakarta : Pustaka Pelajar

Tangkilisan, Hassel Nogi S. 2005. Kebijakan dan Manajemen Otomo Daerah. Yogyakarta : Lukman Offset.

Wahab, Solichin Abdul. 20II. Analisis Kebijakan Publik. Jakarta.

Winarni, 2012. Pedoman Pengelolaan Pusat Informasi dan Konseling Remaja dan Mahasiswa (PIK Remaja IMahasiswa). Jakarta : BKKBN

Wirdhana, Indra, 2013. Kurikulum Diklat Teknis Pengelolaan PIK Remaja/Mahasiswa Bagi Pengelola, Pendidik Sebaya dam Konselor Sebaya PIK Remaja/Mahasiswa. Jakarta : BKKBN. 